\title{
Compositions and flux of soil gas in Liu-Huang-Ku hydrothermal area, northern Taiwan
}

\author{
Tefang Faith Lan ${ }^{\text {a }}$, Tsanyao Frank Yang ${ }^{\text {a,* }}$, Hsiao-Fen Lee ${ }^{\text {a }}$, Yue-Gau Chen ${ }^{\text {a }}$, \\ Cheng-Hong Chen ${ }^{\mathrm{a}}$, Sheng-Rong Song ${ }^{\mathrm{a}}$, Shuhjong Tsao ${ }^{\mathrm{b}}$ \\ a Department of Geosciences, National Taiwan University, No. 1, Sec. 4, Roosevelt Road, Taipei 106, Taiwan, ROC \\ ${ }^{\mathrm{b}}$ Central Geological Survey, MOEA P.O. Box 968, Taipei 235, Taiwan, ROC
}

Received 30 August 2006; accepted 23 April 2007

Available online 17 May 2007

\begin{abstract}
Soil $\mathrm{CO}_{2}$ flux has been considered a useful proxy to remotely monitor volcanic activity in a hydrothermal area within a safe distance. The Liu-Huang-Ku (LHK) area, which is close to the Taipei basin and many existing active fumaroles and hot springs, was chosen for the first systematic soil gas study in a hydrothermal area of Taiwan in 2004 and 2006. The soil $\mathrm{CO}_{2}$ flux was measured by the closed-chamber method with a non-dispersive infrared detector. Soil $\mathrm{CO}_{2}$ emission rate was estimated $19.8 \pm 0.2 \mathrm{t}$ day $^{-1}$ and $582 \mathrm{t} \mathrm{km}^{-2}$ day $^{-1}$ in 2004, and $22.4 \pm 0.2 \mathrm{t} \mathrm{day}^{-1}$ and $659 \mathrm{t} \mathrm{km}^{-2}$ day $^{-1}$ in 2006 , respectively. These values are close to those reported for other active high $\mathrm{CO}_{2}$ flux hydrothermal areas of the world. It implies that magmatic gases are actively degassing from subsurface in northern Taiwan. Helium and carbon isotopic data reveal that soil gas in LHK is mainly derived from the mantle and is mixed with a small amount of crustal and air components. The abundance of soil $\mathrm{CO}_{2}$ shows a positive correlation with the ${ }^{3} \mathrm{He} /{ }^{4} \mathrm{He}$ ratios and total sulfur contents, which are considered as magmatic-sensitive indicators for the fumarolic samples. Therefore, soil $\mathrm{CO}_{2}$ could be used as a good proxy for future monitoring of magmatic activity in this area.
\end{abstract}

(C) 2007 Elsevier B.V. All rights reserved.

Keywords: soil $\mathrm{CO}_{2}$ flux; closed-chamber method; monitoring; magmatic activity; Taiwan

\section{Introduction}

Soil gas surveys have been widely applied in the geosciences for decades, e.g. oil and mineral exploration, hydrothermal investigations, earthquake and volcanic eruption precursory studies, environmental pollution, active fault location and so on (e.g. Lombardi and Reimer, 1990; Suchomel et al., 1990; Klusman, 1993; King et al., 1996; Chiodini et al., 1998; Baubron et al., 2002; Chyi et al., 2005; Fu et al., 2005; Walia et al., 2005a,b; Yang et al., 2005b, 2006b). Anomalous climatic changes in

\footnotetext{
* Corresponding author. Tel.: +88623366 5874; fax: +8862 23636095

E-mail address: tyyang@ntu.edu.tw (T.F. Yang).
}

recent years has provoked questions to whether the huge amount of greenhouse gases emitted from active and mud volcanoes might significantly affect the global climate (Pales and Keeling, 1965; Etiope, 1999). Therefore, a precise estimation of the diffuse gas emission is important to define any relationship between degassing and global climate change.

Important for volcanic surveys and monitoring, a large volume of volcanic gas is often released to the atmosphere through craters and/or soil, regardless of whether the volcanoes are erupting or passively degassing. The variation of volcanic gas flux is considered as an important index of volcanic activity. $\mathrm{CO}_{2}$ is the most abundant component after water, and is also one of the 
earliest and less reactive gases departing from the ascending magma (e.g. Syomnds et al., 1994; Giggenbach, 1996). Therefore, $\mathrm{CO}_{2}$ is easily detected and observed in early stages of magma uprising in one area. Several techniques have been developed to measure $\mathrm{CO}_{2}$ flux, whereby the $\mathrm{CO}_{2}$ concentration is measured with a portable airborne mounted IR spectrometer, or the flux of $\mathrm{SO}_{2}$ is measured and the $\mathrm{CO}_{2}$ flux calculated from the known ratio between the two gases. In volcanic areas, a high $\mathrm{CO}_{2}$ concentration may appear not only in the region close to craters and fumaroles, but also in areas far from apparent gas conduits (Allard et al., 1991). Thus, people could monitor volcanoes by soil gases at a safe distance. Furthermore, a contour map of soil $\mathrm{CO}_{2}$ flux can also provide information of the characteristics and structures of volcanoes.

Taiwan is located at the collisional boundary of Eurasia and Philippine Sea plate. Different tectonic models have been proposed to explain the magma activity in northern Taiwan (e.g. Teng et al., 1992; Teng, 1996; Wang et al., 1999). Integrated mineralogical and stratigraphical data shows that the latest eruption may have occurred around $20 \mathrm{ka}$ in the Tatun volcanic area in northern Taiwan (Chen and Lin, 2002), where hydro- thermal activity is still active. Recent seismic (Yeh and Chen, 1991; Lin et al., 2005a,b) and geochemical data (Yang et al., 1999, 2005a; Lee et al., 2005) infer that a magma chamber may exist under northern Taiwan, hence, support the idea that the Tatun Volcano Group (TVG) may be still active (Song et al., 2000b).

The objective of this paper is to assess the feasibility of using the soil gas method to monitor the potential volcanic activity in this region. The relationship between soil gas and fumarolic gas compositions in the studied area will be also discussed. Lin et al. (2005a,b) reported some volcanic-seismic signals which are believed to be related to local hydrothermal activity. Continuous monitoring result also showed that the temperature of fumarolic gas in TVG has been increasing from 2004 until recent (Lee et al., 2006). In addition to regular sampling and analysis of fumarolic gas, we try to utilize a different monitoring method that enables us to safely monitor volcanoes in case of more vigorous volcanic activity. Therefore, the Liu-Huang-Ku (LHK) hydrothermal area, which is one of the most fumarole- and hot spring-active areas in TVG and administratively in the populated Taipei City, was chosen as a testing location for the first soil gas study in a hydrothermal area of

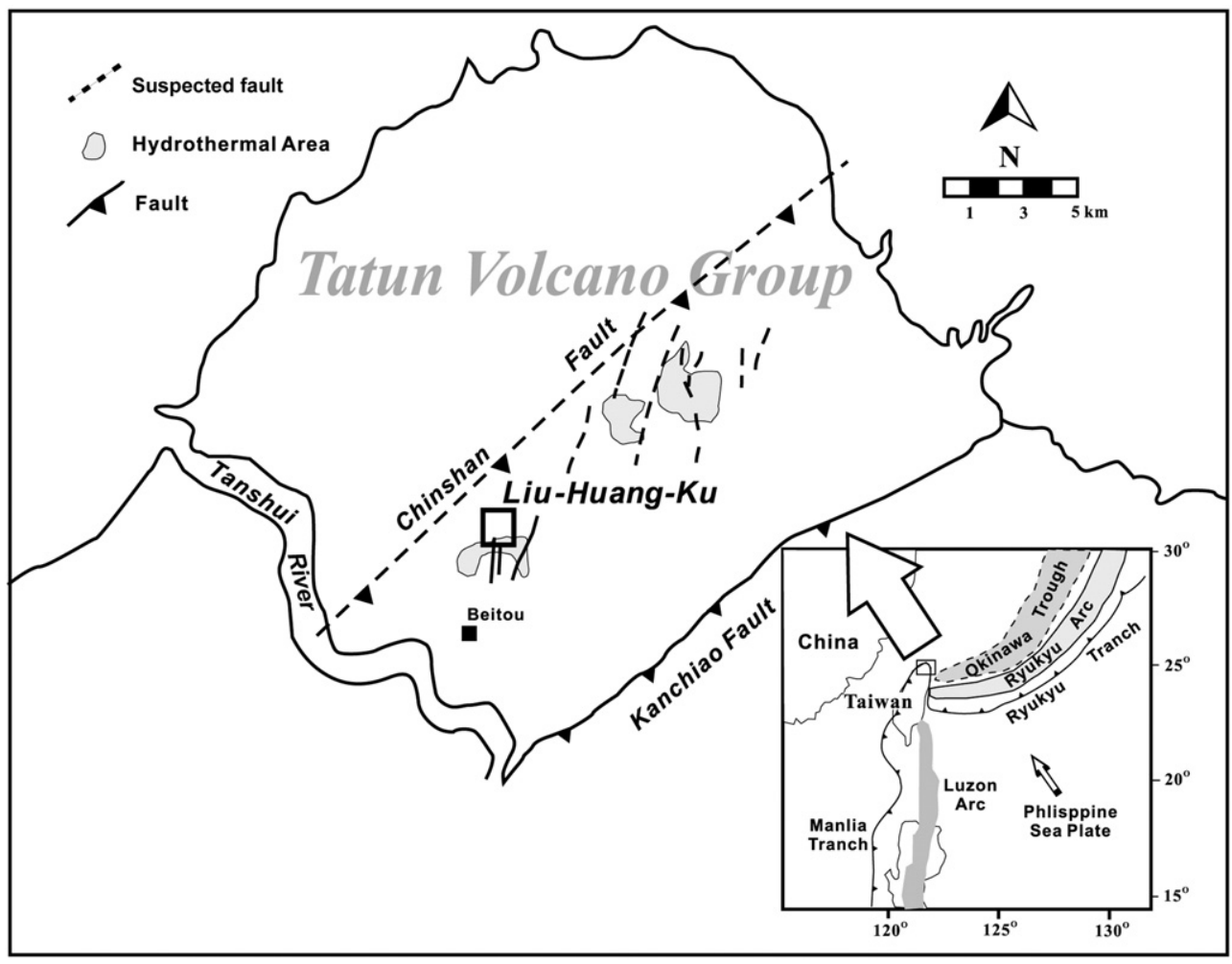

Fig. 1. Illustration of the principal tectonics of Taiwan and Tatun Volcano Group. Liu-Huang-Ku is located at the southwest part of Tatun Volcano Group. 
Taiwan in 2004. The same work was duplicated in 2006 to compare the possible temporal variations of soil gas composition in the area.

\section{Liu-Huang-Ku hydrothermal area}

LHK hydrothermal area, formed ca. 0.8 to 0.6 million years ago (Song et al., 2000a), is a $1 \mathrm{~km}$ long, $150 \mathrm{~m}$ wide phreatic crater located on the hillside of southwest TVG with several steaming fumaroles and artificial hot springs utilized as resources of nearby hotels (Fig. 1). Fumarolic gas composition of TVG samples reflects a mixing signature between convergent plate gases and air/groundwater (Lee et al., 2005). This suggests that the magma source of the TVG gas is closely associated with the subduction system in NE Taiwan. The bed rocks are mostly hydrothermal-altered lower Miocene sedimentary rocks. The unaltered Wuchihshan Formation is composed of white sandstones and interbedded with thin layers of shale and coal, while the Mushan Formation contains quartzite sandstone, gray-to-black shale and coal (Ho, 1988).

\section{Methods and procedures}

\subsection{Fieldwork in Liu-Huang-Ku}

Chiodini et al. (1998) have described and compared some methods for soil flux measurement, including the indirect, direct, static and closed-chamber methods. These authors suggested that the closed-chamber method may be more suitable than others in the field. They further modified the method by using a hermetically sealed chamber on the soil from which the increase of $\mathrm{CO}_{2}$ concentration in the chamber can be measured to derive flux. This method was successfully applied to agricultural sciences to measure the soil metabolism (Parkinson, 1981) and flux of other gas species (e.g. Kinzig and Socolow, 1994). This method has also been tested by Tonani and Miele (1991) as the

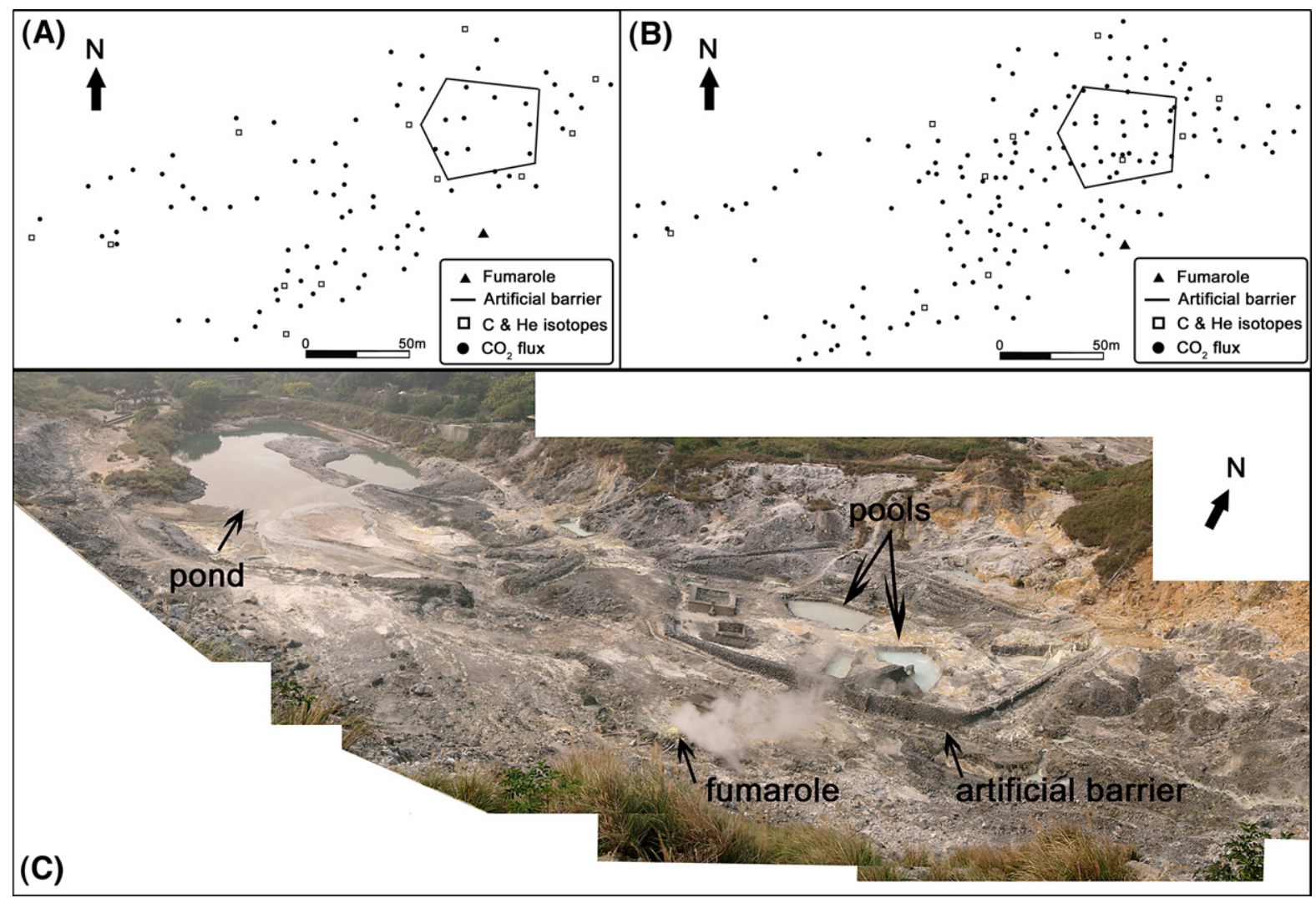

Fig. 2. Sampling sites at Liu-Huang-Ku in this study. (A) $94 \mathrm{CO}_{2}$ flux measurement points (solid circles) and 11 isotopic samples (squares) in 2004 (B) $163 \mathrm{CO}_{2}$ flux measurement points (solid circles) and 10 isotopic samples (squares) in 2006. The pentagon is the artificial barrier as shown in the photograph. (C) Photograph of LHK, which is a steam-eruptive crater with many fumaroles and spring pools. 
Table 1

Estimated parameters of partitioned populations of soil $\mathrm{CO}_{2}$ flux in Liu-Huang-Ku hydrothermal area

\begin{tabular}{lcccc}
\hline Population & $\begin{array}{l}\text { Proportion } \\
(\%)\end{array}$ & $\begin{array}{l}\text { Sample } \\
\text { quantity }\end{array}$ & $\begin{array}{l}\text { Mean } \mathrm{CO}_{2} \text { flux and } 95 \% \text { confidence interval } \\
\left(\mathrm{g} \mathrm{m}^{-2} \mathrm{day}^{-1}\right)\end{array}$ & $\begin{array}{l}\text { Total diffuse } \mathrm{CO}_{2} \text { output and 95\% confidence interval } \\
\left(\mathrm{t} \mathrm{day}^{-1}\right)\end{array}$ \\
\hline 2004 survey & & & & \\
A & 38 & 37 & $25(16-33.3)$ & $0.32(0.21-0.43)$ \\
B & 56 & 52 & $521(361-680)$ & $9.92(6.87-13.0)$ \\
C & 6 & 5 & $4678(3035-6321)$ & $9.54(6.19-12.9)$ \\
Total & 100 & 94 & & $19.8(13.3-26.3)$ \\
& & & $21(16.5-25.8)$ & \\
2006 survey & 34 & 56 & $711(552-870)$ & $0.24(0.19-0.30)$ \\
A & 63 & 101 & $6866(5652-8079)$ & $7.2(11.8-18.6)$ \\
B & 63 & 6 & & $22.4(17.8-27.1)$ \\
C & 3 & 163 & &
\end{tabular}

Area $=34,000 \mathrm{~m}^{2}$.

preferable way to measure flux of volcanological and geothermal areas because it does not require any assumptions or corrections for soil characteristics, like grain size, porosity, permeability etc.

We adopted the closed-chamber method to determine the soil $\mathrm{CO}_{2}$ flux by using a commercial portable flux meter (West System, Italy). The system is composed of three parts: (1) Non-dispersed Infrared (NDIR) Gas Sensors (LICOR LI820): for measuring $\mathrm{CO}_{2}$ concentration. (2) Circular chamber: a hermetically sealed chamber with a volume of $6.2 \times 10^{-3} \mathrm{~m}^{3}$, and a height of $0.2 \mathrm{~m}$. An inlet and an outlet make the system as a circular loop. A capillary is assembled to the top of the chamber for balancing pressure ins and outs. A fan is equipped in the chamber to well-mix air and soil gas. (3) Pocket PC: for equipment control and data storage. To prevent the contamination of water vapor, we use silica gel as the water trap. Before measuring flux, the rim of chamber was covered by soil and sealed well, or leakage of air might influence flux significantly especially in windy days. Furthermore, pressure in the chamber is maintained nearly equal to the air, or duration of measurement would last longer (Welles et al., 2001). Error of this method is $\pm 10 \%$ evaluated by laboratory experiments with replicate measurements of known effluxes. In addition to the soil flux measured with the closed-chamber method, a stainless steel probe ( $1 \mathrm{~m}$ in length, $1 \mathrm{~cm}$ diameter) was inserted into soil to at least $50 \mathrm{~cm}$ depth, the gas then pumped into preevacuated low-permeability sample bottles for isotope analysis. Detailed procedures and method of soil gas sampling and analysis were described by Fu et al. (2005).

Soil $\mathrm{CO}_{2}$ flux measurements were conducted in 2004 and 2006. In the first survey, 94 sites were measured in the study area (Fig. 2) from January to February of 2004, during the dry season in northern Taiwan. The second survey was conducted in February 2006, 163 sites were measured under similar meteorological condition to avoid the influence of weather factors. Soil temperature (measured at the depth of ca. $15 \mathrm{~cm}$ ) and atmospheric pressure were recorded at the same time for calibration. In addition, representative soil gas samples were also collected for measurement of the carbon and helium isotopic compositions to distinguish their gas sources.

\subsection{Analyses of soil gas compositions and isotopes}

Soil gas compositions were analyzed by a gas chromatograph (GC, SRI 8610C), equipped with two thermal conductivity detectors (TCDs) and one flame ionic detector (FID). One Hayesep-D column uses hydrogen as a carrier gas, whereas a MS5A column uses argon as a carrier gas. Analyses of fumarolic gas composition were conducted using the same method described by Lee et al. (2005). Concentration and isotopic ratio of helium, neon and other noble gas were analyzed by a high-precision noble gas mass spectrometer (Micromass 5400) using potassium-glass bottles with vacuum stopcocks at both ends. Observed ${ }^{3} \mathrm{He} /{ }^{4} \mathrm{He}$ ratios were calibrated against atmospheric standard gas and normalized to the $R_{\mathrm{A}}$, where $R_{\mathrm{A}}$ is the air ${ }^{3} \mathrm{He} /{ }^{4} \mathrm{He}$ ratio equal to $1.39 \times 10^{-6}$. The overall error of the ratio, including analytical error of the sample and working standard gas, and long-term variations of the standards, was less than 2.5\% (Yang et al., 2005a, 2006a). After purification of soil gas samples by traps held at liquid $\mathrm{N}_{2}$ and ethanol-dry ice temperatures, carbon isotopes of carbon dioxide were analyzed using a Finnigan MAT mass spectrometer. Measured ${ }^{13} \mathrm{C} /{ }^{12} \mathrm{C}$ ratios are expressed in the delta $(\delta)$ notation, as parts per thousand (\%o) compared to the international standard, PDB. The experimental error on the carbon isotopic ratios was $\sim 0.1 \%$ (Hsieh, 2000). 


\section{Results and discussion}

\subsection{Spatial distribution of $\mathrm{CO}_{2}$ flux and soil temperature}

A large quantity of literature has been published on the feasibility of using soil flux measurements to detect active structures such as fractures and faults in a volcanic area (e.g. Giammanco et al., 1998; Baubron et al., 2002; Finizola et al., 2003; Alparone et al., 2004; Giammanco et al., 2006). However, a spatial distribution of soil flux in a hydrothermal area not only indicates the structures and/or fractures, but also associates to the possible positions of heat sources.

The soil $\mathrm{CO}_{2}$ flux in LHK area shows a wide range from 16 to $8079 \mathrm{~g} \mathrm{~m}^{-2}$ day $^{-1}$ in this study (Table 1). The spatial distribution of the $\mathrm{CO}_{2}$ flux is shown as Fig. 3 using Krigging method with interpolation based on a linear variogram model. Due to some severe strikes of typhoons in 2005; the landscape of LHK area changed somehow. Masses of sands and mud were carried into the valley-like area and buried two spring pools; some originally immeasurable hard-ground was covered by soil. Therefore the study area became larger and the number of $\mathrm{CO}_{2}$ flux data was increased from 94 in 2004 to 163 in 2006 . Due to the changes of ground surface, remeasurement at the exact same locations is difficult; however, from a large scale of geographical distribution, the resembling NE-SW distributed pattern can be observed (Fig. 3), which is probably associated with the structure in this area (Song, 1994). This observation

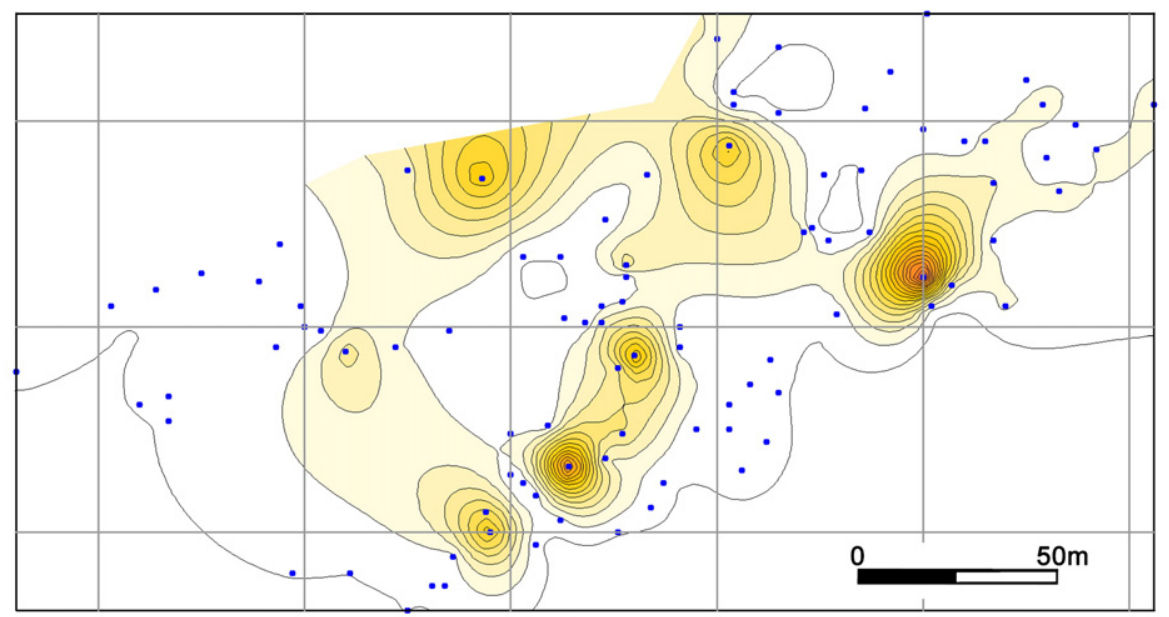

Soil $\mathrm{CO}_{2}$ flux

$\left(\mathrm{g} \mathrm{m}^{-2} \mathrm{~d}^{-1}\right)$
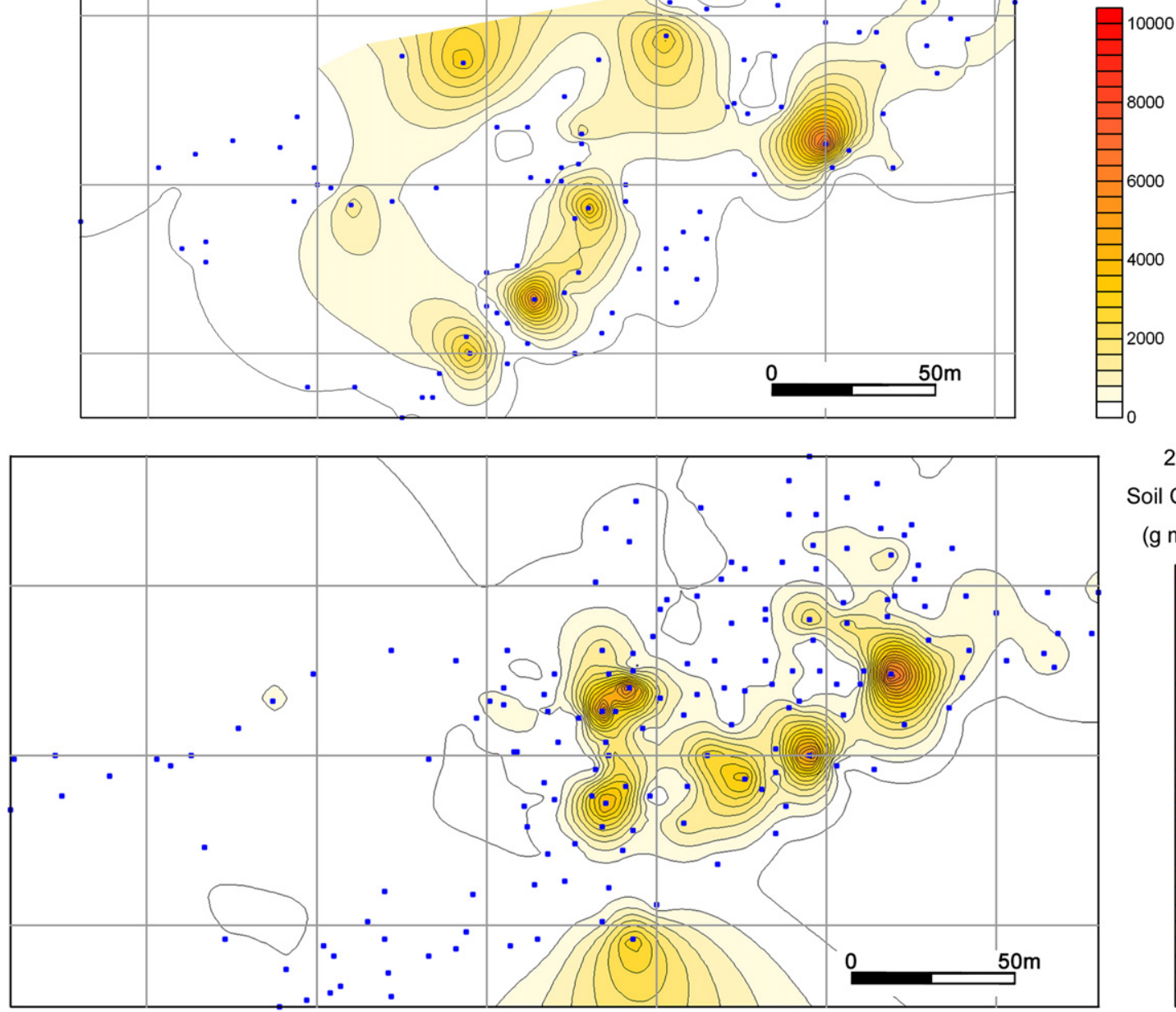

2006

Soil $\mathrm{CO}_{2}$ flux

$\left(\mathrm{g} \mathrm{m}^{-2} \mathrm{~d}^{-1}\right)$

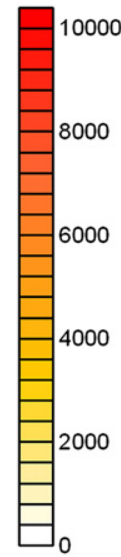

Fig. 3. Contour map of soil $\mathrm{CO}_{2}$ flux of LHK with reference to sampling sites (dots) same as in Fig. 2A (upper) and Fig. 2B (lower). 
could also help us to identify the displacement of heat sources or structures.

Comparing the $\mathrm{CO}_{2}$ flux (Fig. 3) with the soil temperature (Fig. 4) in LHK, it can be found that they correlate each other sympathetically. This is best explained by a hot degassing source in this area. However, some measured points close to the pond in LHK show decoupling result of lower soil temperature with higher soil $\mathrm{CO}_{2}$ flux. It might be due to the cooling effect of pond water while volcanic gases rising upward to the surface. Yet, higher soil temperature with lower $\mathrm{CO}_{2}$ flux at some sites was found in the 2006 survey. It might be due to local changes of the permeability and porosity of the soil in the studied area during the typhoon season in 2005. A high temperature volcanic gas could diffuse through the soil easily and raise the soil temperature; however, if the soil permeability becomes low, gas can transport heat but may not be able to diffuse through the cover layer. This can cause the higher temperature for the soil with only low $\mathrm{CO}_{2}$ flux.

\subsection{Estimation of total $\mathrm{CO}_{2}$ output}

Due to high variability of flux value, a statistical method proposed by Sinclair (1974) was applied to find out how many normal distributions there are in the data sets. Three overlapped populations can be recognized in both the 2004 and 2006 data clusters and grouped in the probability graphs (Fig. 5) with the average flux of

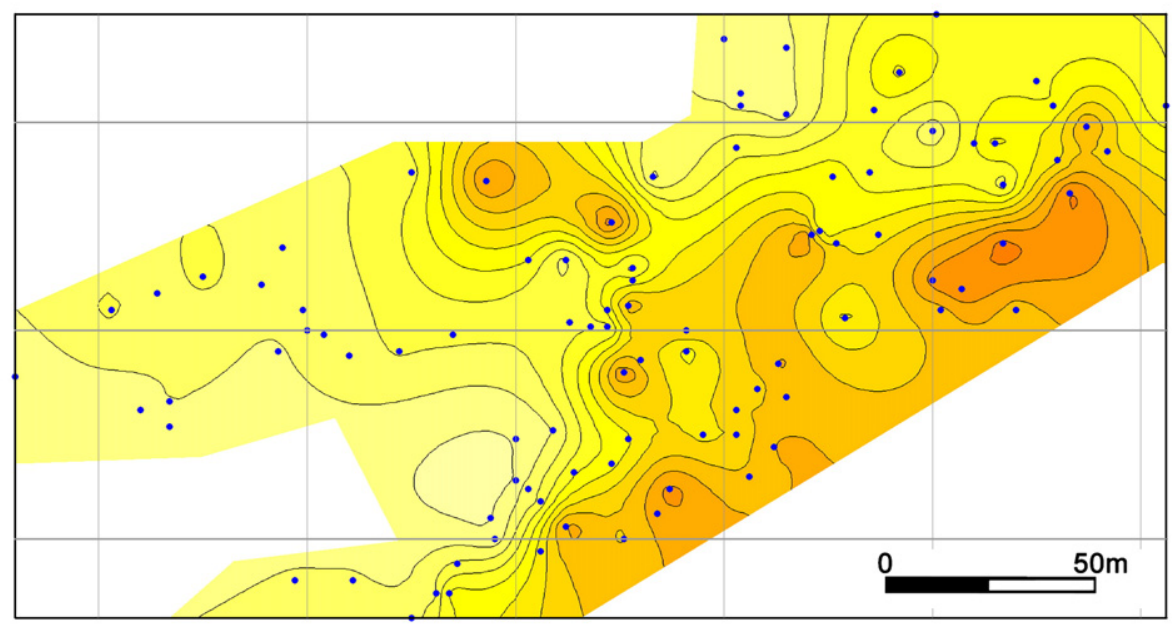

2004

Soil Temperature

$\left({ }^{\circ} \mathrm{C}\right)$
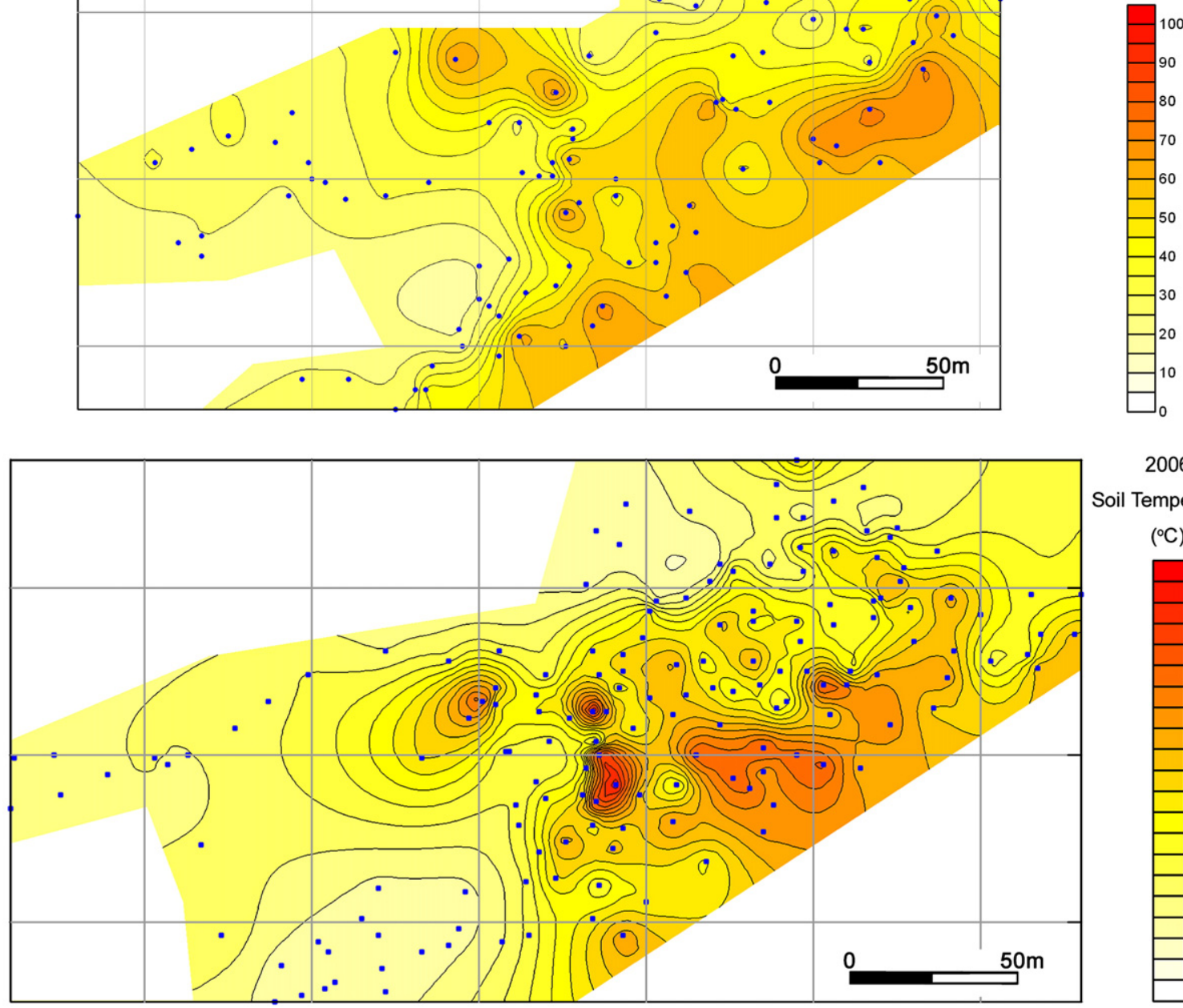

2006 Soil Temperature

$\left({ }^{\circ} \mathrm{C}\right)$

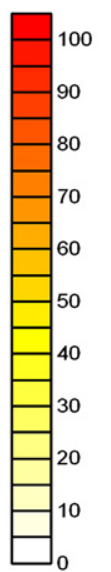

Fig. 4. Contour map of soil temperature of LHK with reference to sampling sites (dots) same as in Fig. 2A (upper) and Fig. 2B (lower). 
populations A, B and $\mathrm{C}$ listed in Table 1. The consequences in 2006, in contrast with data in 2004, present an obvious increase in the average value of population $\mathrm{C}$, and in the meantime population $\mathrm{B}$ rose to $711 \mathrm{~g} \mathrm{~m}^{-2} \mathrm{~d}^{-1}$; yet, population $\mathrm{A}$ remains with relatively the same extent as in 2004. It is noteworthy that the variation of soil gas flux is likely related to the sample size, but enlarging the sample size could increase the precision of the statistical estimation. Therefore, the possible reasons for the increase in soil gas flux could be: (1) more vigorous degassing from the magmatic source; (2) diffusive paths of soil gas in the overall area were more widened than those in 2004. The increase of average soil temperature and the isotopic variation (discussed in later session) support the two assumptions. Hence, it is worthwhile to monitor future possible fluctuation of soil $\mathrm{CO}_{2}$ flux in LHK.

Consequently, emission rates of soil $\mathrm{CO}_{2}$ were estimated by summing the contribution of each population (details described in Chiodini et al., 1998). The results are $19.8 \pm 0.2 \mathrm{tday}^{-1}$ and $22.4 \pm 0.2 \mathrm{tday}^{-1}$ for the survey in 2004 and 2006, respectively. The total $\mathrm{CO}_{2}$ output of LHK is smaller than those of high-flux hydrothermal locations of the world (Table 2) due to

\section{(A)}
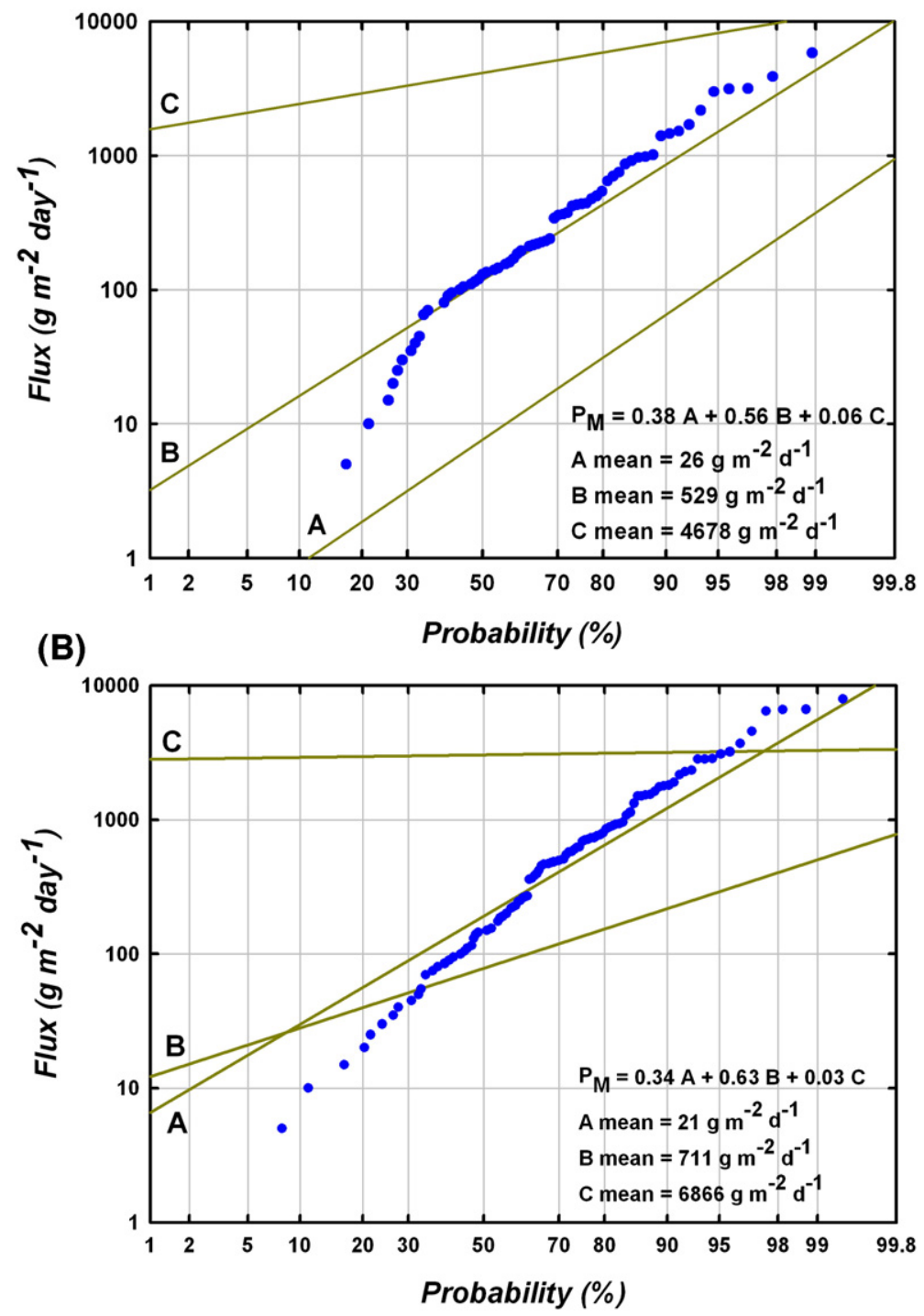

Fig. 5. Cumulative frequency plot of soil $\mathrm{CO}_{2}$ flux of Liu-Huang-Ku in (A) 2004 and (B) 2006. Grey lines represent the partition components of population A, B and C. See text for detail discussion. 
Table 2

Soil $\mathrm{CO}_{2}$ emission rates observed in Liu-Huang-Ku and other volcanic areas of the world

\begin{tabular}{|c|c|c|c|c|}
\hline $\begin{array}{l}\text { Location } \\
\text { (year) }\end{array}$ & $\begin{array}{l}\text { Area } \\
\left(\mathrm{km}^{2}\right)\end{array}$ & $\begin{array}{l}\mathrm{CO}_{2} \text { flux } \\
\left(\mathrm{t} \mathrm{day}^{-1}\right)\end{array}$ & $\begin{array}{l}\mathrm{CO}_{2} \text { flux } \\
\left(\mathrm{t} \mathrm{km}^{-2} \mathrm{day}^{-1}\right)\end{array}$ & Reference \\
\hline Liu-Huang-Ku, Taiwan (2004) & 0.034 & 19.8 & 582 & This study \\
\hline Liu-Huang-Ku, Taiwan (2006) & 0.034 & 22.4 & 659 & This study \\
\hline Miyakejima, Japan (1998) & 0.62 & 146 & 235 & [1] \\
\hline Hakkoda, Japan, September (1999) & 0.58 & 74 & 120 & {$[2]$} \\
\hline Yanbajain, China (1996) & 3.2 & 138 & 43.1 & {$[3]$} \\
\hline Vulcano, Italy (1995) & 0.65 & 269 & 414 & {$[4]$} \\
\hline Solfatara of Pozzuoli, Italy (1994) & 0.09 & 133 & 1478 & {$[4]$} \\
\hline Etna, Italy (1981) & n.d. & 55,000 & n.d. & {$[5]$} \\
\hline Summit Teide, Spain (1996) & 0.53 & 380 & 717 & {$[6]$} \\
\hline Mammoth Mountain, USA (1995) & 0.145 & 350 & 2414 & {$[7]$} \\
\hline Mammoth Mountain, USA (1997) & 0.145 & 130 & 897 & {$[7]$} \\
\hline
\end{tabular}

[1] Hernández et al. (2001); [2] Hernández Perez et al. (2003); [3] Chiodini et al. (1998); [4] Chiodini et al. (1996); [5] Allard et al. (1987, 1991); [6] Hernández et al. (1998); [7] Gerlach et al. (1998); n.d. = no data.

relative smaller surveyed area in this study. However, the results of the emission rates with per unit area (Table 2) reveal that soil $\mathrm{CO}_{2}$ output from LHK corresponds to that of other high soil $\mathrm{CO}_{2}$ flux areas in the world with $582 \mathrm{t} \mathrm{km}^{-2}$ day $^{-1}$ in 2004 and $659 \mathrm{t}$ $\mathrm{km}^{-2}$ day $^{-1}$ in 2006 .

\subsection{Compositions and sources of soil gas}

The composition of soil gas in LHK resembles that of fumarolic gas, defined as having the typical composition of a low temperature fumarolic gas (i.e. high $\mathrm{CO}_{2}$ concentration and the ratio of $\mathrm{H}_{2} \mathrm{~S} / \mathrm{SO}_{2}>1$ ). The major component is water ( $>85 \%$ ) followed by $\mathrm{N}_{2}, \mathrm{CO}_{2}, \mathrm{O}_{2}$ and $\mathrm{Ar}$ as shown in Table 3. Lee et al. (2005) proposed that the compositions of most TVG gas (including LHK) exhibit affinity with convergent plate gases based on the plot of $\mathrm{N}_{2}-\mathrm{He}-\mathrm{Ar}$ (Fig. 6). This suggests that the degassing sources for TVG gases are closely related to the subduction process in NE Taiwan.

By using $\mathrm{CO}_{2} /{ }^{3} \mathrm{He}-\delta^{13} \mathrm{C}_{\mathrm{CO}_{2}}$ mixing model proposed by Sano and Marty (1995), we can estimate the

Table 3

Chemical compositions and helium isotopic data of soil gas in Liu-Huang-Ku hydrothermal area

\begin{tabular}{|c|c|c|c|c|c|c|c|c|c|c|c|}
\hline Sample & $\begin{array}{l}\mathrm{N}_{2} \\
(\%) \\
\end{array}$ & $\begin{array}{l}\mathrm{O}_{2} \\
(\%) \\
\end{array}$ & $\begin{array}{l}\mathrm{Ar} \\
(\%)\end{array}$ & $\begin{array}{l}\mathrm{H}_{2} \mathrm{~S} \\
(\%)\end{array}$ & $\begin{array}{l}\mathrm{SO}_{2} \\
(\%)\end{array}$ & $\begin{array}{l}\mathrm{CO}_{2} \\
(\%)\end{array}$ & ${ }^{4} \mathrm{He} /{ }^{20} \mathrm{Ne}$ & ${ }^{3} \mathrm{He} /{ }^{4} \mathrm{He}$ & $R_{A}$ & Error & $\begin{array}{l}\mathrm{He} \\
(\mathrm{ppm})\end{array}$ \\
\hline \multicolumn{12}{|c|}{ Soil gas sampled in 2004} \\
\hline 2004LHK-S1 & 81.90 & 13.90 & 0.94 & 0.06 & 0.01 & 3.19 & 0.32 & $1.372 \times 10^{-6}$ & 0.99 & 0.04 & 5.48 \\
\hline 2004LHK-S2 & 77.48 & 17.62 & 0.91 & 0.09 & 0.02 & 3.88 & 0.38 & $1.676 \times 10^{-6}$ & 1.21 & 0.04 & 6.47 \\
\hline 2004LHK-S3 & 14.25 & 2.73 & 0.13 & 8.05 & 0.05 & 74.78 & 11.19 & $8.808 \times 10^{-6}$ & 6.34 & 0.10 & 8.37 \\
\hline 2004LHK-S4 & 72.91 & 14.54 & 0.80 & 0.11 & 0.03 & 11.61 & 0.32 & $1.459 \times 10^{-6}$ & 1.05 & 0.03 & 4.70 \\
\hline 2004LHK-S5 & 6.20 & 0.81 & 0.04 & 6.79 & 0.02 & 86.13 & 14.90 & $8.292 \times 10^{-6}$ & 5.97 & 0.10 & 5.10 \\
\hline 2004LHK-S9-1 & 51.31 & 11.41 & 0.54 & 0.97 & 0.04 & 35.73 & 0.95 & $5.806 \times 10^{-6}$ & 4.18 & 0.06 & 7.04 \\
\hline 2004LHK-S9-2 & 43.36 & 9.83 & 0.46 & 2.39 & 0.02 & 43.95 & 0.80 & $6.122 \times 10^{-6}$ & 4.40 & 0.08 & 6.93 \\
\hline 2004LHK-S12 & 29.27 & 6.11 & 0.30 & 4.25 & 0.07 & 60.00 & 1.29 & $6.522 \times 10^{-6}$ & 4.69 & 0.08 & 5.54 \\
\hline \multicolumn{12}{|c|}{ Soil gas sampled in 2006} \\
\hline 2006LHK-S1 & 75.88 & 16.45 & 0.88 & 0.06 & 0.00 & 6.72 & 0.36 & $1.57 \times 10^{-6}$ & 1.13 & 0.03 & 5.53 \\
\hline 2006LHK-S2 & 12.88 & 2.46 & 0.09 & 9.14 & 0.03 & 75.40 & 6.93 & $8.00 \times 10^{-6}$ & 5.76 & 0.09 & 7.92 \\
\hline 2006LHK-S4 & 11.77 & 2.20 & 0.08 & 11.46 & 0.04 & 74.46 & 15.14 & $8.22 \times 10^{-6}$ & 5.91 & 0.10 & 7.48 \\
\hline 2006LHK-S5 & 7.81 & 0.44 & 0.02 & 5.68 & 0.08 & 85.97 & 16.33 & $8.33 \times 10^{-6}$ & 5.99 & 0.09 & 7.87 \\
\hline 2006LHK-S6 & 13.58 & 2.33 & 0.10 & 6.81 & 0.04 & 77.14 & 6.48 & $8.05 \times 10^{-6}$ & 5.79 & 0.10 & 7.41 \\
\hline 2006LHK-S7 & 10.28 & 1.98 & 0.06 & 7.60 & 0.03 & 80.07 & 8.22 & $8.01 \times 10^{-6}$ & 5.76 & 0.09 & 7.32 \\
\hline 2006LHK-S8 & 4.81 & 0.63 & 0.02 & 12.71 & 0.03 & 81.80 & 4.19 & $7.62 \times 10^{-6}$ & 5.48 & 0.09 & 6.79 \\
\hline 2006LHK-S9 & 8.29 & 1.24 & 0.04 & 7.57 & 0.04 & 82.82 & 4.61 & $7.98 \times 10^{-6}$ & 5.74 & 0.09 & 7.47 \\
\hline 2006LHK-S10 & 81.90 & 14.41 & 0.90 & 0.06 & 0.00 & 2.74 & 0.33 & $1.63 \times 10^{-6}$ & 1.17 & 0.03 & 5.55 \\
\hline
\end{tabular}


proportion of each component for carbon source in a fumarolic gas sample. The calculation formulas are defined as follows:

$$
\begin{aligned}
\left({ }^{13} \mathrm{C} /{ }^{12} \mathrm{C}\right)_{\mathrm{Obs}}= & M\left({ }^{13} \mathrm{C} /{ }^{12} \mathrm{C}\right)_{M}+L\left({ }^{13} \mathrm{C} /{ }^{12} \mathrm{C}\right)_{L} \\
& +S\left({ }^{13} \mathrm{C} /{ }^{12} \mathrm{C}\right)_{S}
\end{aligned}
$$

$$
\begin{aligned}
1 /\left({ }^{12} \mathrm{C} /{ }^{3} \mathrm{He}\right)_{\mathrm{Obs}}= & M /\left({ }^{12} \mathrm{C} /{ }^{3} \mathrm{He}\right)_{M} \\
& +L /\left({ }^{12} \mathrm{C} /{ }^{3} \mathrm{He}\right)_{L} \\
& +S /\left({ }^{12} \mathrm{C} /{ }^{3} \mathrm{He}\right)_{S}
\end{aligned}
$$

$M+L+S=1$

in which $M$ : magmatic source, $L$ : marine limestone, $S$ : sediments; and Obs: observed data of the sample.

Table 4 shows the calculated percentages of soil gas from magmatic source, sediments and limestone. The range of componential percentage of LHK soil gas is: $M=7-19 \%, L=63-85 \%, S=2-28 \%$ which is similar to that of TVG fumarolic gas (Table 4, Yang et al., 2003) and that from subduction zones in the world: $M=7-$ $17 \%, L=63-75 \%, S=17-28 \%$ (Sano and Marty, 1995). Data on the plot of $\delta^{13} \mathrm{C}_{\mathrm{CO}_{2}}$ versus $\mathrm{CO}_{2} /{ }^{\beta} \mathrm{He}$ (Fig. 7A) indicate the source of soil gas from LHK bears a resemblance to volcanic gas from other island-arc areas (Sano and Marty, 1995). The high proportion of carbonate component commonly found in a subducting environment (Table 4, Sano and Marty, 1995; Shaw et al., 2003) are considered to be attributed to the subducted calcareous sediments and/or limestone interbedded in the basement rocks of upper crust.

The mixing characteristics of soil gas and fumarolic gas in LHK are shown in Fig. 8 in terms of three end members: air, crust and mantle. It is seen that the helium isotopic composition of fumarolic gas is about 5 to $6 R_{\mathrm{A}}$ with a very small amount of air contamination. The features of soil gas dominant with high ${ }^{3} \mathrm{He} /{ }^{4} \mathrm{He}$ ratios are taken for representatives of fumarolic gas, they are in contrast with those which are as low as air compositions. Furthermore, a wellmixing relationship between air and the magmatic source of LHK is also illustrated. This implies that the migration channels of some soil gas measuring sites might be totally replaced by fumaroles, otherwise a more crustal signature should be observed. High total sulfur content and ${ }^{3} \mathrm{He} /{ }^{4} \mathrm{He}$ ratio are two most important features of volcanic gas. In Fig. 9A, it can be seen that there is a positive correlation between total sulfur content and soil $\mathrm{CO}_{2}$ concentration; a similar relation is also found between $\mathrm{CO}_{2}$ and ${ }^{3} \mathrm{He} /{ }^{4} \mathrm{He}$ ratios (Fig. 9B). Therefore, the concentration of soil $\mathrm{CO}_{2}$ in LHK indicates the abundance of magmatic gas. Conclusively, we suggest that $\mathrm{CO}_{2}$ is a good proxy for future monitoring in this area because it is not only an efficient parameter but also inexpensive for measuring.

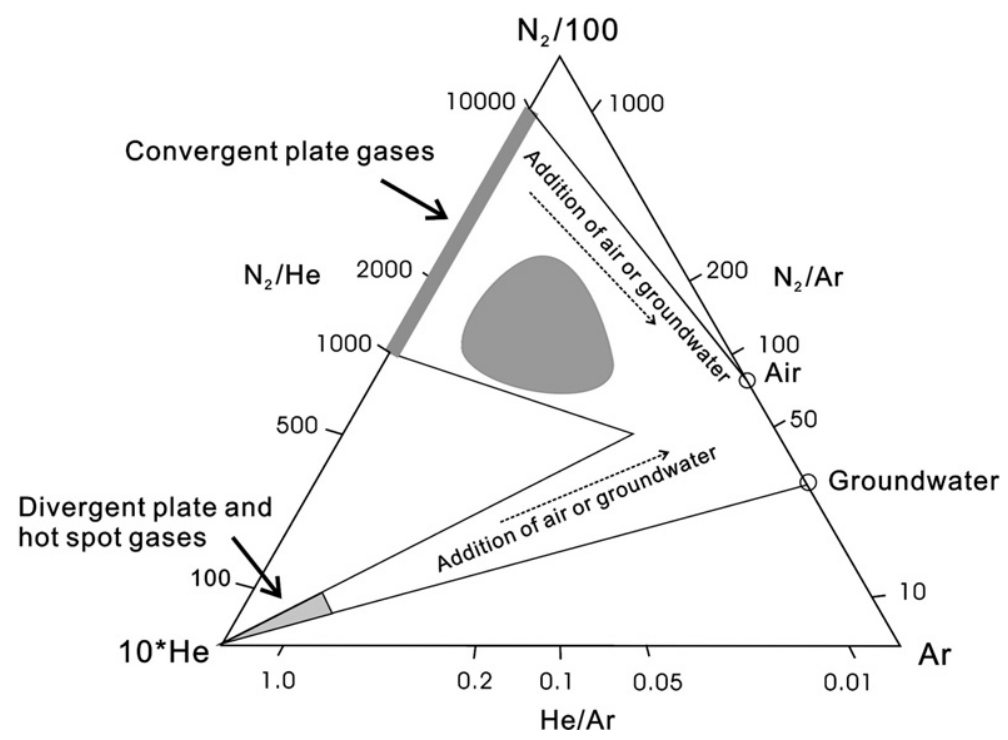

Fig. 6. $\mathrm{N}_{2}-\mathrm{He}-\mathrm{Ar}$ triangular plot of fumarolic gas from LHK. The shadowed area is the average composition of fumarolic gas from LHK which falls within the range of convergent plate gases mixing with air/groundwater. Data from Lee et al. (2005). 
Table 4

Helium and carbon isotopes, $\mathrm{CO}_{2}{ }^{\beta} \mathrm{He}$ ratios and estimated sources of carbon in gas and fluids from LHK and subduction zones

\begin{tabular}{|c|c|c|c|c|c|c|c|}
\hline \multirow[t]{2}{*}{ No. name } & \multirow[t]{2}{*}{$R_{\mathrm{A}}$} & \multirow{2}{*}{$\begin{array}{l}\delta^{13} \mathrm{C}_{\mathrm{CO} 2} \\
(\% \circ)\end{array}$} & \multirow[t]{2}{*}{$\mathrm{CO}_{2} /{ }^{3} \mathrm{He}$} & \multicolumn{3}{|c|}{ Carbon sources } & \multirow[t]{2}{*}{ References } \\
\hline & & & & $\begin{array}{l}\text { Magmatic } \\
(\%)\end{array}$ & $\begin{array}{l}\text { Sediment } \\
(\%)\end{array}$ & $\begin{array}{l}\text { Limestone } \\
(\%)\end{array}$ & \\
\hline \multicolumn{8}{|l|}{ Soil gas of $L H K$} \\
\hline 2004-LHK-S3 & 0.99 & -6.07 & $4.24 \times 10^{9}$ & 14.8 & 17.0 & 68.2 & This study \\
\hline 2004-LHK-S4 & 1.21 & -9.02 & $3.58 \times 10^{9}$ & 8.79 & 28.2 & 63.1 & This study \\
\hline 2004-LHK-S5 & 6.34 & -5.90 & $1.01 \times 10^{10}$ & 7.03 & 18.1 & 74.6 & This study \\
\hline 2004-LHK-S9-1 & 1.05 & -7.20 & $1.69 \times 10^{10}$ & 17.1 & 20.0 & 62.6 & This study \\
\hline 2004-LHK-S9-2 & 5.97 & -6.91 & $2.04 \times 10^{10}$ & 14.3 & 19.9 & 65.7 & \multirow[t]{2}{*}{ This study } \\
\hline Average & 3.11 & -7.02 & $1.10 \times 10^{10}$ & 12.4 & 20.6 & 66.8 & \\
\hline 2006-LHK-S1 & 1.13 & -2.17 & $7.74 \times 10^{9}$ & 19.3 & 3.05 & 77.7 & This study \\
\hline 2006-LHK-S2 & 5.76 & -1.45 & $1.19 \times 10^{10}$ & 12.5 & 2.12 & 85.4 & This study \\
\hline 2006-LHK-S4 & 5.91 & -2.51 & $1.21 \times 10^{10}$ & 12.3 & 5.71 & 82.0 & This study \\
\hline 2006-LHK-S5 & 5.99 & -3.63 & $1.31 \times 10^{10}$ & 11.4 & 9.65 & 79.0 & This study \\
\hline 2006-LHK-S6 & 5.79 & -4.17 & $1.29 \times 10^{10}$ & 11.5 & 11.4 & 77.1 & This study \\
\hline 2006-LHK-S7 & 5.76 & -3.93 & $1.37 \times 10^{10}$ & 10.9 & 10.7 & 78.4 & This study \\
\hline 2006-LHK-S8 & 5.48 & -5.32 & $1.58 \times 10^{10}$ & 9.43 & 15.7 & 74.9 & This study \\
\hline Average & 5.12 & -3.31 & $1.25 \times 10^{10}$ & 12.5 & 8.3 & 79.2 & \\
\hline \multicolumn{8}{|c|}{ Fumarolic gas of TVG } \\
\hline LHK & 5.62 & -3.15 & $1.22 \times 10^{10}$ & 12.2 & 7.9 & 79.9 & [1] \\
\hline SYK & 4.88 & -3.40 & $1.28 \times 10^{10}$ & 11.6 & 8.8 & 79.5 & [1] \\
\hline DYK & 6.79 & -6.34 & $7.01 \times 10^{10}$ & 2.1 & 20.7 & 77.2 & [1] \\
\hline MS & 4.55 & -5.56 & $1.33 \times 10^{10}$ & 11.2 & 16.1 & 72.7 & [1] \\
\hline CSL & 5.92 & -3.04 & $1.32 \times 10^{10}$ & 11.3 & 7.7 & 81.0 & [1] \\
\hline TYK & 4.49 & -3.73 & $3.97 \times 10^{10}$ & 3.7 & 11.6 & 84.6 & [1] \\
\hline SHP & 3.78 & -3.28 & $7.61 \times 10^{10}$ & 1.9 & 10.5 & 87.5 & [1] \\
\hline \multicolumn{8}{|c|}{ Gas and fluids from subduction zones (Medium and low-temperature fumarole within caldera) } \\
\hline Shinmoe, Japan & 5.98 & -4.9 & $2.79 \times 10^{10}$ & 5 & 15 & 80 & {$[2],[3]$} \\
\hline Vulcano, Italy & 4.96 & -2.0 & $7.40 \times 10^{9}$ & 20 & 2 & 78 & [4], [5] \\
\hline Purace, Colombia & 6.19 & -8.5 & $6.58 \times 10^{9}$ & 23 & 23 & 54 & [6] \\
\hline Oshima, Japan & 5.08 & -1.3 & $2.40 \times 10^{10}$ & 6 & 3 & 91 & [7] \\
\hline Ebino, Japan & 5.87 & -3.9 & $1.75 \times 10^{10}$ & 9 & 11 & 80 & [3] \\
\hline
\end{tabular}

[1] Yang et al. (2003); [2] Sano and Wakita (1985); [3] Urabe (1985); [4] Marty et al. (1989); [5] Shinohara and Matsuo (1986); [6] Sturchio et al. (1992); [7] Sano et al. (1994). The shaded italic data highlight the average compositions of soil and fumarole samples in LHK for comparison.

\subsection{Temporal variation of carbon isotopes}

It is interesting to note the difference between data obtained in 2004 and 2006. The average percentages of the three sources of carbon shown in Table 4 reveal a variation in the sediment and limestone components, whereas the magmatic source is about constant. Moreover, the average values of the carbon isotopic ratio and calculated proportions of each component from the 2006 data are very close to results obtained for fumarolic gas (Yang et al., 1999, 2003). The helium isotopic composition was also similar to that measured in fumarolic gas. In fact, results of 2004 and 2006 can be grouped into two distinct data sets with an apparent shift toward a heavier carbon isotopic composition in 2006 (Fig. 7B). Moreover, the total sulfur contents in 2006 were also higher than in 2004 , increasing from $8.1 \%$ in 2004 to $12.7 \%$ in 2006, a value closer to that measured in fumarolic gas. However, difference between the data sets of ${ }^{3} \mathrm{He} /{ }^{4} \mathrm{He}$ ratios plotted on the air-crust-mantle diagram (Fig. 8) cannot be identified.

There are two possible explanations for these phenomena as mentioned: (1) a change in the gas sources, (2) a modification within the path of gas uprising. The former is unlikely due to a steady helium isotopic composition, i.e. the variation is within a range of two standard deviations in the past few years, in this area (Lee et al., 2006). The monitoring results of the fumarolic gas composition and temperature showed some 


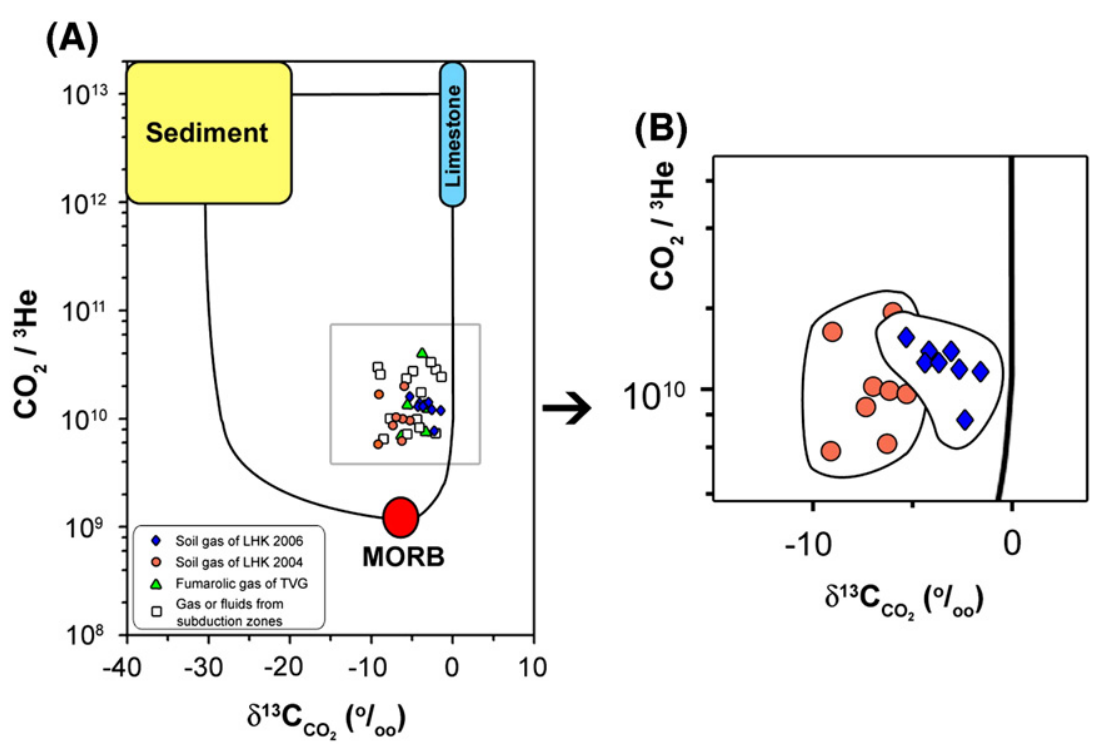

Fig. 7. Correlation between $\mathrm{CO}_{2}{ }^{\beta} \mathrm{He}$ and $\delta^{13} \mathrm{C}$. (A) Soil gas of Liu-Huang-Ku is mainly derived from a mantle component and has a typical composition for its location in an island-arc area. (B) Two distinct data sets can be identified from samples in 2004 and 2006.

increasing trend since August, 2004 (Lee et al., 2006). However, the helium isotopic composition remained stable, indicating that there was no new magmatic signature involved in this event but probably the opening of gas paths. Nevertheless the significant increase towards a heavier carbon isotopic signal is clear. It is reasonable to speculate the opening of gas paths in this area since northern Taiwan is now under extension tectonic settings. With regard to the second speculation, the recent isotopic components and total sulfur contents of soil gas resemble analyses of fumarolic gas, in contrast to those in 2004, implying a common source. If the gas source were remained unchanged, the paths for gas emission through the soil in LHK would have been similar to that of the fumaroles. This also reinforces the feasibility of adopting soil gas as a replacement of fumarolic gas as a suitable monitoring parameter in LHK. However, this

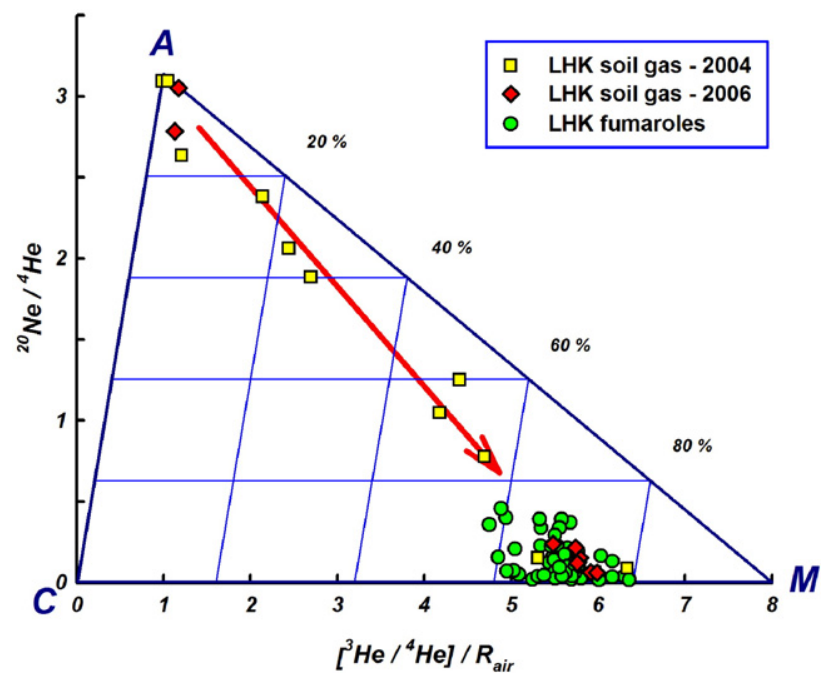

Fig. 8. Correlation between ${ }^{20} \mathrm{Ne} /{ }^{4} \mathrm{He}$ and $\left[{ }^{3} \mathrm{He} /{ }^{4} \mathrm{He}\right] / R_{\text {air }}$. Gas of fumaroles (circle) is mainly derived from mantle and mixes with small amount of crust. A distinct trend of air-mantle mixing is seen for the compositions of soil gas sampled in 2004 (square) and 2006 (diamond). 

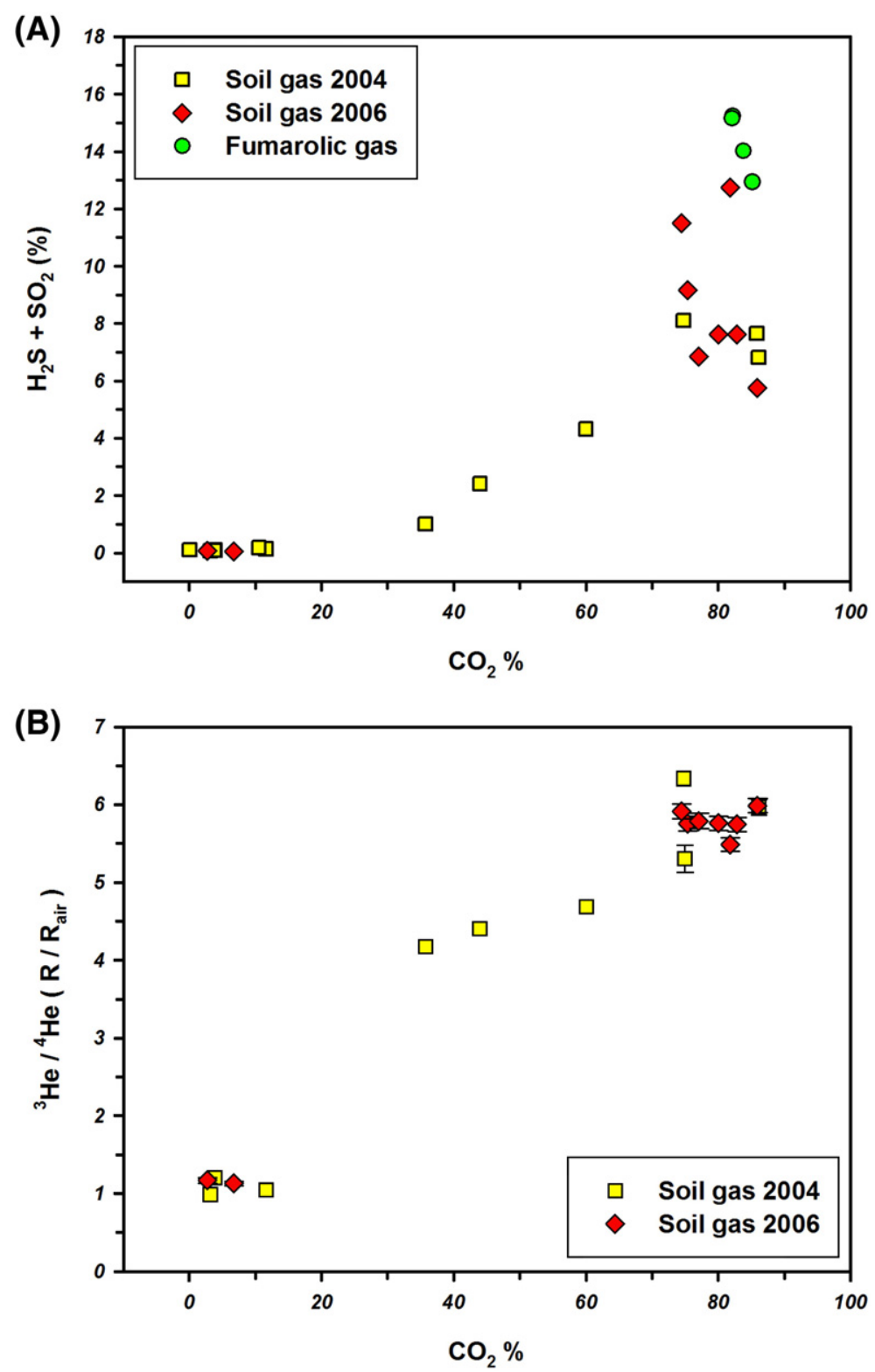

Fig. 9. Variation diagrams of (A) total sulfur vs. soil $\mathrm{CO}_{2}$ concentration; (B) He isotopic ratio vs. soil $\mathrm{CO}_{2}$ concentration. Samples with high $\mathrm{CO}_{2}$ abundance also have high total sulfur contents and $R_{\mathrm{A}}$ values. Abundance of soil $\mathrm{CO}_{2}$ therefore represents the abundance of magmatic gas composition, which could be a good proxy of future monitoring in the area.

needs to be confirmed through further monitoring in the future.

\section{Concluding remarks}

The study has confirmed the feasibility of using the closed-chamber method to measure the soil $\mathrm{CO}_{2}$ flux in the Tatun Volcano Group. The calculated soil $\mathrm{CO}_{2}$ emission rates from Liu-Huang-Ku in 2004 and 2006 are $19.8 \pm 0.2$ and $22.4 \pm 0.2 \mathrm{t} \mathrm{day}^{-1}$ respectively. Further- more, the soil $\mathrm{CO}_{2}$ output per unit area was 582 and $659 \mathrm{t}$ $\mathrm{km}^{-2}$ day ${ }^{-1}$ respectively, which is similar to other areas in the world with high soil $\mathrm{CO}_{2}$ flux. The spatial distribution of soil $\mathrm{CO}_{2}$ flux indicates the locations of possible heat sources and/or fractures in Liu-Huang-Ku. Helium and carbon isotopic data reveal that the principle magmatic source of soil gas is the mantle. The results of the isotopic composition of soil gas and its temporal variation support the conclusion that soil $\mathrm{CO}_{2}$ can be a potential parameter for future monitoring in this area. 


\section{Acknowledgements}

We thank Mr. B. W. Lin and C. C. Wang, and Dr. V. Walia for their assistance in collecting samples and isotopic analysis. Drs. G. Saito, G. Chiodini, D. Bergfeld, T. Ohba kindly gave valuable suggestions on the measurement of soil flux. Drs. T. Ohba and N. Varley carefully reviewed the paper and gave critical comments to improve the manuscript. National Science Council and Central Geological Survey of Taiwan, R.O. C. financially support this study (TFL/NSC91-2815-C002-086-M; TFY/5226902000-05-93-01).

\section{References}

Allard, P., Le Bronce, J., Morel, P., Vavasseur, C., Faivre-Pierret, R., Robe, M.C., Roussel, C., Zettwoog, P., 1987. Geochemistry of soil gas emanations from Mt. Etna, Sicily. Terra Cognita 7 (G17-52), 407.

Allard, P., Carbonelle, J., Dajlevic, D., Le Bronce, J., Morel, P., Robe, M.C., Maurenads, J.M., Faivre-Pierret, R., Martin, D., Sabroux, J.C., Zettwoog, P., 1991. Eruptive and diffusive emissions of $\mathrm{CO}_{2}$ from Mount Etna. Nature 351, 387-391.

Alparone, S., Andronico, S., Giammanco, S., Lodato, L., 2004. A multidisciplinary approach to detect active pathways for magma migration and eruption at Mt. Etna (Sicily, Italy) before the 2001 and 2002-2003 eruptions. Journal of Volcanology and Geothermal Research 136, 121-140.

Baubron, J.C., Rigo, A., Toutain, J.P., 2002. Soil gas profiles as a tool to characterise active tectonic areas: the Jaut Pass example (Pyrenees, France). Earth and Planetary Science Letters 196, 69-81.

Chen, C.-H., Lin, S.B., 2002. Eruptions younger than $20 \mathrm{Ka}$ of the Tatun Volcano Group as viewed from the sediments of the Sungshan Formation in Taipei Basin. Western Pacific Earth Sciences 2, 191-204.

Chiodini, G., Frondini, F., Raco, B., 1996. Diffuse emission of $\mathrm{CO}_{2}$ from the Fossa crater, Vulcano Island (Italy). Bulletin of Volcanology 58, 41-50.

Chiodini, G., Cioni, R., Guidi, M., Raco, B., Marini, L., 1998. Soil $\mathrm{CO}_{2}$ flux measurements in volcanic and geothermal areas. Applied Geochemistry 13, 543-552.

Chyi, L.L., Quick, T.J., Yang, T.F., Chen, C.-H., 2005. Soil gas radon spectra and earthquakes. Terrestrial, Atmospheric and Oceanic Sciences 16, 763-774.

Etiope, G., 1999. Subsoil $\mathrm{CO}_{2}$ and $\mathrm{CH}_{4}$ and their transfer from faulted grassland to atmosphere. Journal of Geophysical Research 104, 16889-16894.

Finizola, A., Sortino, F., Lénat, J.-F., Aubert, M., Ripepe, M., Valenza, M., 2003. The summit hydrothermal system of Stromboli. New insights from self-potential, temperature, $\mathrm{CO}_{2}$ and fumarolic fluid measurements, with structural and monitoring implications. Bulletin of Volcanology 65, 486-504.

Fu, C.C., Yang, T.F., Walia, V., Chen, C.-H., 2005. Reconnaissance of soil gas composition over the buried fault and fracture zone in southern Taiwan. Geochemical Journal 39, 427-439.

Gerlach, T., Doukas, M., McGee, K., Kessler, R., 1998. Three-year decline of magmatic $\mathrm{CO}_{2}$ emission from soils of a Mammoth Mountain tree kill: Horseshoe Lake, CA, 1995-1997. Geophysical Research Letters 25, 1947-1950.
Giammanco, S., Gurrieri, S., Valenza, M., 1998. Anomalous soil $\mathrm{CO}_{2}$ degassing in relation to faults and eruptive fissures on Mount Etna (Sicily, Italy). Bulletin of Volcanology 60, 252-259.

Giammanco, S., Gurrieri, S., Valenza, M., 2006. Fault-controlled soil $\mathrm{CO}_{2}$ degassing and shallow magma bodies: Summit and lower East Rift of Kilauea Volcano (Hawaii), 1997. Pure and Applied Geophysics 163, 853-867.

Giggenbach, W.F., 1996. Chemical composition of volcanic gases. In: Scarpa, R., Tillinh, R.I. (Eds.), Monitoring and Mitigation of Volcanic Hazards. Springer, Berlin, pp. 221-256.

Hernández, P.A., Pérez, N.M., Salazar, J.M., Notsu, K., Wakita, H., 1998. Diffuse emission of carbon dioxide, methane, and helium-3 from Teide volcano, Tenerife, Canary Islands. Geophysical Research Letters 25, 3311-3314.

Hernández, P., Salazar, J.M., Shimoike, Y., Mori, T., Notsu, K., Pérez, N., 2001. Diffuse emission of $\mathrm{CO}_{2}$ from Miyakejima volcano, Japan. Chemical Geology 177, 175-185.

Hernández Perez, P., Notsu, K., Tsurumi, M., Mori, T., Ohno, M., Shimoike, Y., Salazar, J., Pérez, N., 2003. Carbon dioxide emissions from soils at Hakkoda, north Japan. Journal of Geophysical Research 108 (B4), 2210. doi:10.1029/2002JB001847.

Ho, C.S., 1988. An introduction to the geology of Taiwan explanatory text of the geologic map of Taiwan. Central Geological Survey, MOEA. 163pp. (in Chinese).

Hsieh, P.S., 2000. The gas sources of hot springs and mud volcanoes in Taiwan. MS Thesis, Institute of Geosciences, National Taiwan University, 77 pp. (in Chinese).

King, C.-K., King, B.-S., Evans, W.C., Zang, W., 1996. Spatial radon anomalies on active faults in California. Applied Geochemistry 11, 497-510.

Kinzig, A.P., Socolow, R.H., 1994. Human impact on the nitrogen cycle. Physics Today 47 (11), 24-31.

Klusman, R.W., 1993. Soil Gas and Related Methods for Natural Resource Exploration. Wiley, England. 483pp.

Lee, H.F., Yang, T.F., Lan, T.F., Song, S.R., Tsao, S., 2005. Fumarolic gas composition of the Tatun Volcano Group, northern Taiwan. Terrestrial, Atmospheric and Oceanic Sciences 16, 843-864.

Lee, H.F., Yang, T.F., Lan, T.F., Song, S.R., Tsao, S., 2006. The variations of fumarolic gas compositions in Tatun Volcano Group, Northern Taiwan. Eos, Transactions of the American Geophysical Union 87 (52) (Fall Meet. Suppl., Abstract V23C0646).

Lin, C.H., Konstantinou, K.I., Liang, W.T., Pu, H.C., Lin, Y.M., You, S.H., Huang, Y.P., 2005a. Preliminary analysis of volcanoseismic signals recorded at the Tatun Volcano Group, northern Taiwan. Geophysical Research Letters 32, L10313. doi:10.1029/2005GL022861.

Lin, C.H., Konstantinou, K.I., Pu, H.C., Hsu, C.C., Lin, Y.M., You, S.H., Huang, Y.P., 2005b. Preliminary results of seismic monitoring at Tatun volcanic area of northern Taiwan. Terrestrial, Atmospheric and Oceanic Sciences 16, 563-577.

Lombardi, S., Reimer, G.M., 1990. Radon and helium in soil gases in the Phlegrean Fields, Central Italy. Geophysical Research Letters 17, 849-952.

Marty, B., Jambon, A., Sano, Y., 1989. Helium isotopes and $\mathrm{CO}_{2}$ in volcanic gases in Japan. Chemical Geology 76, 25-40.

Pales, J.C., Keeling, C.D., 1965. The concentration of atmospheric carbon dioxide in Hawaii. Journal of Geophysical Research 70, 6053-6076.

Parkinson, K.J., 1981. An improved method for measuring soil respiration in the field. Journal of Applied Ecology 18, 221-228.

Sano, Y., Marty, B., 1995. Origin of carbon in fumarolic gas from island arcs. Chemical Geology 119, 265-274. 
Sano, Y., Wakita, H., 1985. Geographical distribution of ${ }^{3} \mathrm{He} /{ }^{4} \mathrm{He}$ ratios in Japan: implications for arc tectonics and incipient magmatism. Journal of Geophysical Research 90, 8729-8741.

Sano, Y., Gamo, T., Notsu, K., Wakita, H., 1994. Secular variations of helium and carbon isotopes at Izu-Oshima volcano, Japan. Journal of Volcanology and Geothermal Research 61, 83-94.

Shaw, A.M., Hilton, D.R., Fischer, T.P., Walker, J.A., Alvarado, G.E., 2003. Contrasting $\mathrm{He}-\mathrm{C}$ relationships in Nicaragua and Costa Rica: insights into $\mathrm{C}$ cycling through subduction zones. Earth and Planetary Science Letters 214, 499-513.

Shinohara, H., Matsuo, S., 1986. Results of analyses on fumarolic gases from F-1 and F-5 fumaroles of Vulcano, Italy. Geothermics $15,211-215$.

Sinclair, A.J., 1974. Selection of thresholds in geochemical data using probability graphs. Journal of Geochemical Exploration 3, 129-149.

Song, R.S., 1994. The research of paleo-volcanic environment and eruptive history of National Yangmingshan Park. Report to Construction and Planning Agency, Minister of Interior (in Chinese).

Song, S.R., Tsao, S.J., Lo, H.J., 2000a. Characteristics of the Tatun volcanic eruptions, north Taiwan: implications for a cauldron formation and volcanic evolution. Journal of the Geological Society of China 43, 361-378.

Song, R.S., Yang, T.F., Yeh, Y.H., Tsao, S., Lo, H.J., 2000b. The Tatun volcano group is active or extinct? Journal of the Geological Society of China 43, 521-534.

Sturchio, N.C., Williams, S.N., Sano, Y., 1992. The hydrothermal system of Purace volcano, Colombia. Bulletin of Volcanology 55, 289-296.

Suchomel, K.H., Kreamer, D.K., Long, A., 1990. Production and transport of carbon dioxide in a contaminated vadose zone: a stable and radioactive carbon isotope study. Environmental Science and Technology 24, 1824-1831.

Syomnds, R.B., Rose, W.I., Bluth, G.S.J., Gerlach, T.M., 1994. Volcanic gas studies: methods, results, and applications. In: Carrol, M.R., Holloway, J.R. (Eds.), Volatiles in Magma. Rev. Mineral. Soc. Am., Washington DC, pp. 1-64.

Teng, L.S., 1996. Extensional collapse of the northern Taiwan mountain belt. Geology 24, 949-952.

Teng, L.S., Chen, C.-H., Wang, W.S., Liu, T.K., Juang, W.S., Chen, J.C., 1992. Plate kinematic model for late Cenozoic arc magmatism in northern Taiwan. Journal of the Geological Society of China 35, $1-18$.

Tonani, F., Miele, G., 1991. Methods for measuring flow of carbon dioxide through soils in the volcanic setting. International
Conference of Active Volcanoes and Risk Mitigation. Napoli. 27 August-1 September 1991.

Urabe, A., 1985. Chemical and isotopic compositions of natural gases in Japan. PhD. Thesis, University of Tokyo, Tokyo.

Walia, V., Su, T.C., Fu, C.C., Yang, T.F., 2005a. Spatial variations of radon and helium concentrations in soil gas across the Shan-Chiao fault, Northern Taiwan. Radiation Measurements 40, 513-516.

Walia, V., Virk, H.S., Yang, T.F., Mahajan, S., Walia, M., Bajwa, B.S., 2005 b. Earthquake prediction studies using radon as a precursor in N-W Himalayas, India: a case study. Terrestrial, Atmospheric and Oceanic Sciences 16, 775-804.

Wang, K.L., Chung, S.L., Chen, C.H., Shinjo, R., Yang, T.F., Chen, C.-H., 1999. Post-collisional magmatism around northern Taiwan and its relation with opening of the Okinawa Trough. Tectonophysics 308, 363-376.

Welles, J.M., Demetriades-Shah, T.H., McDermit, D.K., 2001. Considerations for measuring ground $\mathrm{CO}_{2}$ effluxes with chambers. Chemical Geology 177, 3-13.

Yang, T.F., Sano, Y., Song, S.R., 1999. ${ }^{3} \mathrm{He} /{ }^{4} \mathrm{He}$ ratios of fumaroles and bubbling gases of hot springs in Tatun Volcano Group, North Taiwan. Nuovo Cimento Della Societa Italiana Di Fisica. C 22 (3-4), 281-286.

Yang, T.F., Ho, H.H., Hsieh, P.S., Liu, N.J., Chen, Y.G., Chen, C.-H., 2003. Sources of fumarolic gases from Tatun Volcano Group, North Taiwan. Journal of National Park 13, 127-156 (in Chinese).

Yang, T.F., Lan, T.F., Lee, H.F., Fu, C.C., Chuang, P.C., Lo, C.H., Chen, C.-H., Chen, C.T.A., Lee, C.S., 2005a. Gas compositions and helium isotopic ratios of fluid samples around Kueishantao, NE offshore Taiwan and its tectonic implications. Geochemical Journal 39, 469-480.

Yang, T.F., Walia, V., Chyi, L.L., Fu, C.C., Chen, C.-H., Liu, T.K., Song, S.R., Lee, C.Y., Lee, M., 2005b. Variations of soil radon and thoron concentrations in a fault zone and prospective earthquakes in SW Taiwan. Radiation Measurements 40, 496-502.

Yang, T.F., Chuang, P.C., Lin, S., Chen, J.C., Wang, Y., Chung, S.H., 2006a. Methane venting in gas hydrate potential area offshore of SW Taiwan: evidence of gas analysis of water column samples. Terrestrial, Atmospheric and Oceanic Sciences 17, 933-950.

Yang, T.F., Fu, C.C., Walia, V., Chen, C.-H., Chyi, L.L., Liu, T.K., Song, S.R., Lee, M., Lin, C.W., Lin, C.C., 2006b. Seismo-geochemical variations in SW Taiwan: multi-parameter automatic gas monitoring results. Pure and Applied Geophysics 163, 693-709.

Yeh, Y.H., Chen, K.J., 1991. The Study of Chinshan Fault Microseismic Observation: Report to Hazard Mitigation of National Science Council. 41pp. (in Chinese). 